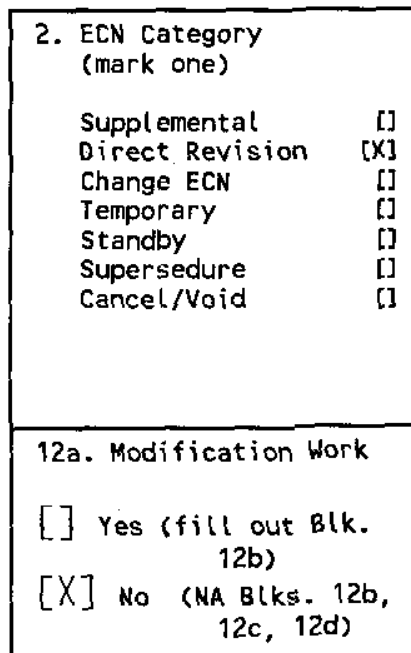

13a. Description of Change Complete revision.
3. Originator's Name, Organization, MSIN, and Telephone No.

Duc M. Nguyen, Data Development and Interpretation, R2-12, 3723042

6. Project Title/No./Work Order No.

Tank 241-ER-311

9. Document Numbers Changed by this ECN (includes sheet no. and rev.) RPP-5375, Rev. 1

4. USQ Required?
[] Yes $[X]$ No

7. Bldg./Sys./Fac. No. $241-E R-311$

10. Related ECN No(s).

ECN-656014
5. Date

$11 / 15 / 99$

8. Approval Designator $N / A$

11. Related PO No. $\mathrm{N} / \mathrm{A}$

12b. Work Package $12 c$. Modification Work Complete $12 d$. Restored to Original CondiNo. $N / A$

$N / A$ tion (Temp. or Standby ECN only) $N / A$

Design Authority/Cog. Engineer Signature \& Date

Design Authority/Cog. Engineer Signature \& Date

13b. Design Baseline Document? [] Yes [X] No

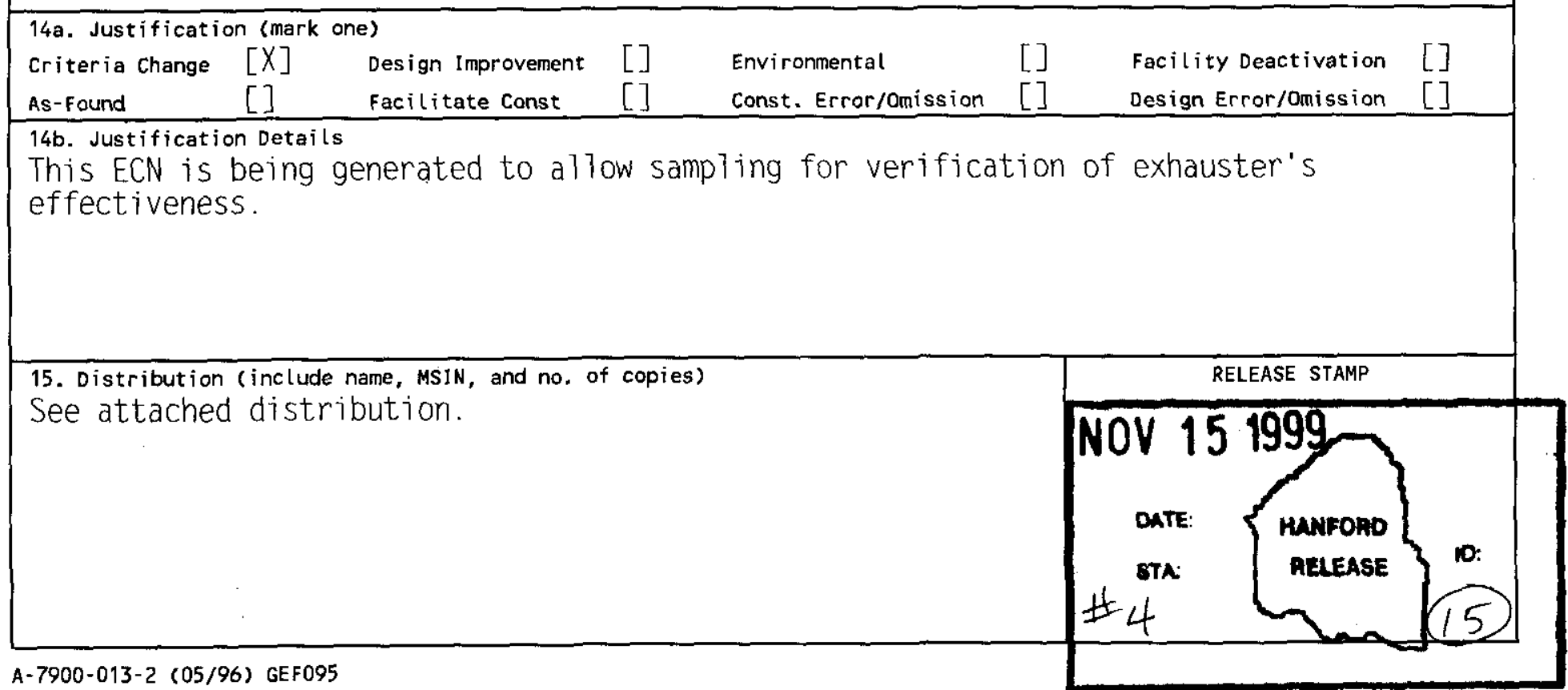




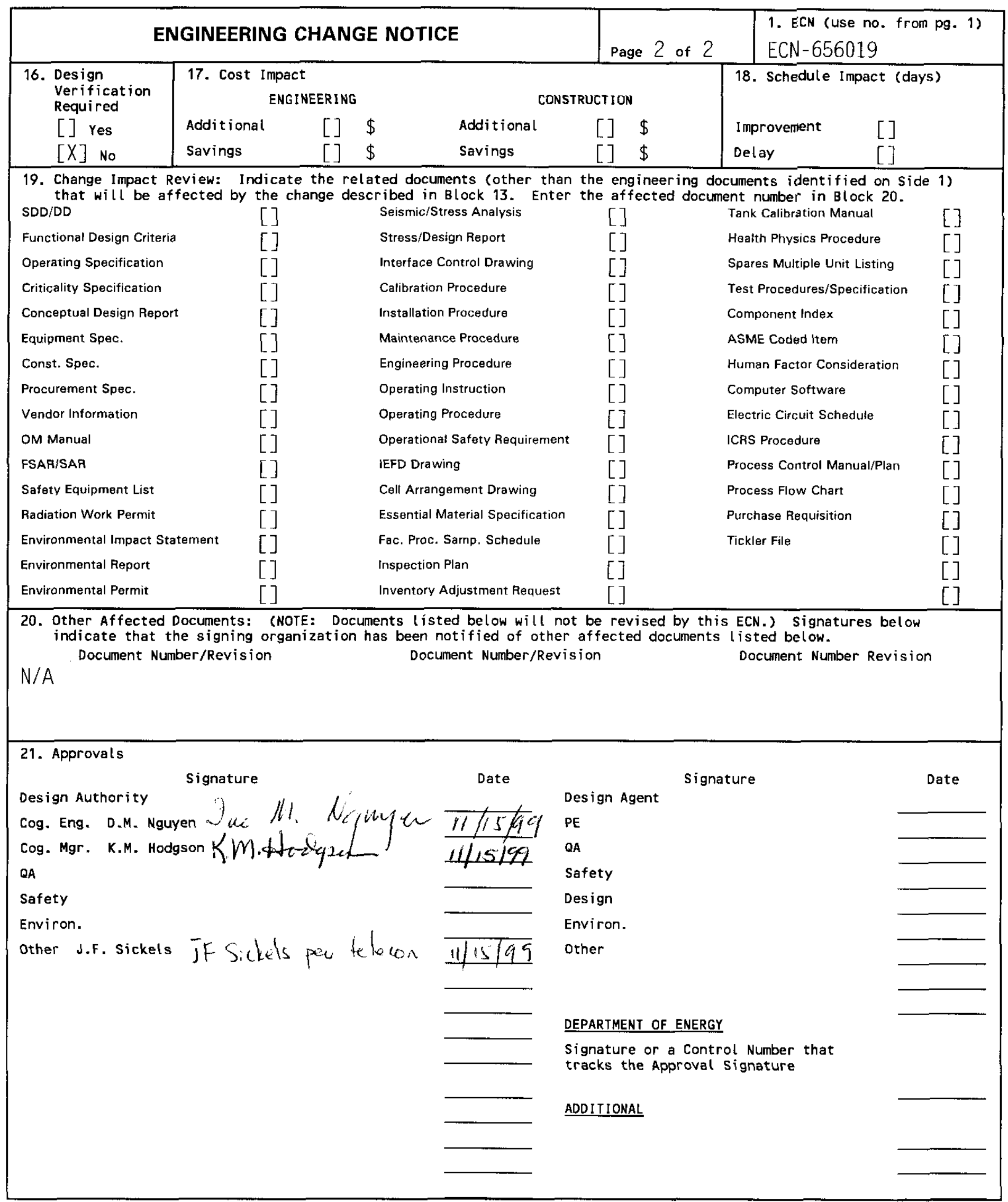




\section{Sampling and Analysis Plan for Catch Tank 241-ER-311 Vapor}

Duc M. Nguyen

Lockheed Martin Hanford, Corp. , Richland. WA 99352

U.S. Department of Energy Contract DE-AC06-96RL13200

EDT/ECN: $E C N-656019$ UC: 2070

Org Code: 74B40 CACN/COA: 102306/ES13

B\&R Code: EW 3120074 Tota] Pages: 10 (JKB"/15/99)

Key words: Tank 241-ER-311, 241-ER-311, ER-311, Catch Tank, Vapor, Sampling. Analysis, Plan

Abstract: N/A

TRADEMARK DISCLAIMER. Reference herein to any specific commercial product, process, or service by trade name, trademark, manufacturer, or otherwise, does not necessarily constitute or imply its endorsement, recommendation, or favoring by the United States Government or any agency thereof or its contractors or subcontractors.

Printed in the United States of America. To obtain copies of this document, contact: Document Control Services, P.O. Box 950, Mailstop H6-08, Richland WA 99352, Phone (509) 372-2420; Fax (509) 376-4989.
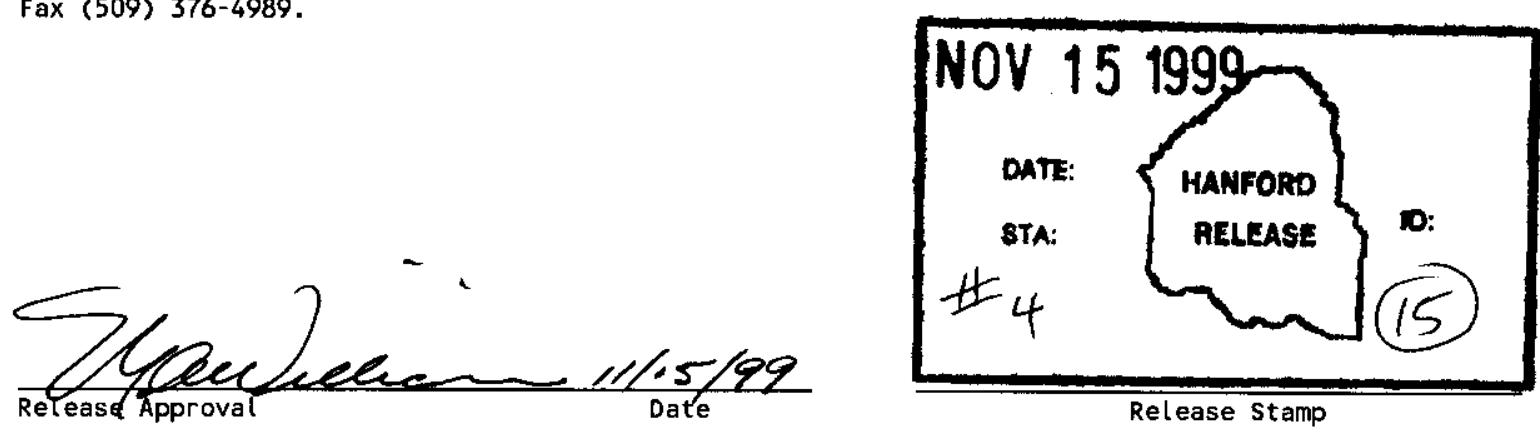

Release Stamp

\section{Approved for Public Release}




\section{RECORD OF REVISION}

(2) Title

Sampling and Analysis Plan for Catch Tank 241 -ER-311 Vapor

CHANGE CONTROL RECORD

\begin{tabular}{|c|c|c|c|}
\hline \multirow{2}{*}{ (3) Revision } & \multirow{2}{*}{ (4) Description of Change - Replace, Add, and Delete Pages } & \multicolumn{2}{|c|}{ Authorized for Release } \\
\hline & & (5) Cog. Engr. & (6) Cog. Mgr. Date \\
\hline 0 & 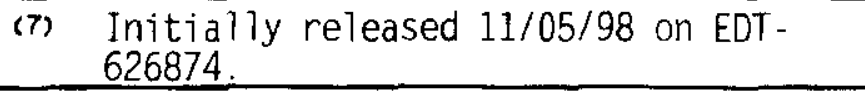 & D.M. Nguyen & K.M. Hodgson \\
\hline $\begin{array}{ll}1 & \\
\text { RS }\end{array}$ & Incorporate per ECN-656014. & D.M. Nguyen & K.M. Hodgson \\
\hline & & moveryens/4 & rintlasge- 1/s/9 \\
\hline $2 R S$ & Incorporate per Een-656019. & D.m.novyen & K.m. Hodgson \\
\hline & & Xinu M. Nowing & h.h. Hodepe \\
\hline & & $1 / 11 / 4$ & $9 \quad 11,5 \% 99$ \\
\hline & & & \\
\hline & & & \\
\hline & & & \\
\hline & & & \\
\hline & & & \\
\hline & & & \\
\hline & & & \\
\hline & & & \\
\hline & & & \\
\hline & & & \\
\hline & & & \\
\hline & & & \\
\hline & & & \\
\hline & & & \\
\hline & & & \\
\hline & & & \\
\hline & & & \\
\hline & & & \\
\hline & & & \\
\hline & & & \\
\hline & & & \\
\hline & & & \\
\hline & & & \\
\hline & & & \\
\hline & & & \\
\hline & & & \\
\hline
\end{tabular}


RPP-5375

Revision 2

\section{SAMPLING AND ANALYSIS PLAN FOR CATCH TANK 241- ER-311 VAPOR}

D. M. Nguyen

Lockheed Martin Hanford Corporation

Date Published

November 1999

Prepared for the U. S. Department of Energy

Assistant Secretary for Environmental Management

Project Hanford Management Contractor for the

U.S. Department of Energy under Contract DE-AC06-96RL13200

Approved for public release; distribution is unlimited 
RPP-5375, Rev. 2

TABLE OF CONTENTS

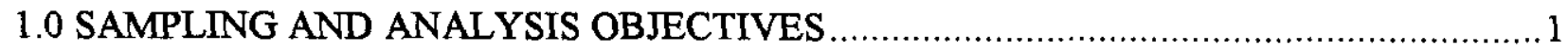

2.0 SAMPLING EVENT REQUIREMENTS ......................................................

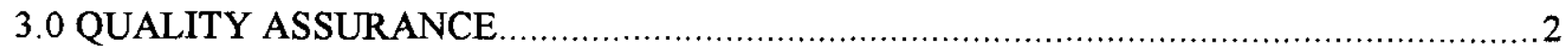

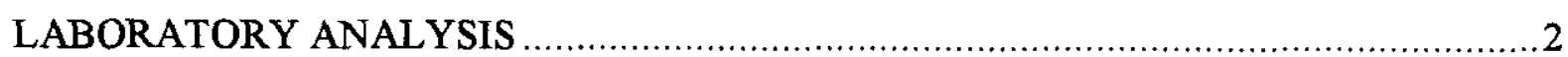

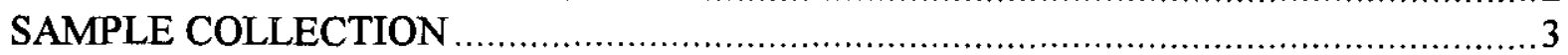

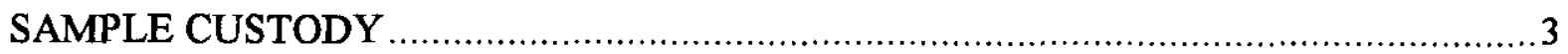

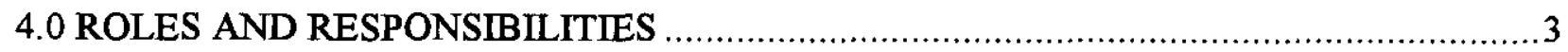

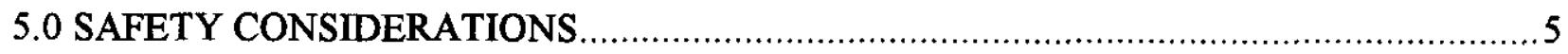

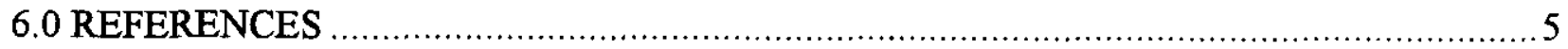


RPP-5375, Rev. 2

\section{LIST OF TERMS}

CGM combustible gas monitor

CPO

Characterization Project Operations

IH\&S Industrial Health and Safety

LFL

PNNL

lower flammability limit

ppm

$\%$

Pacific Northwest National Laboratory

SOP parts per million

percent

standard operating procedure

RPP

River Protection Project 
HNF-5375 Rev. 2

\section{SAMPLING AND ANALYSIS PLAN FOR CATCH TANK 241-ER-311 VAPOR}

\subsection{SAMPLING AND ANALYSIS OBJECTIVES}

This tank sampling and analysis plan (TSAP) identifies the sample collection, laboratory analysis, quality assurance/quality control (QA/QC) objectives for the characterization of catch tank 241-ER-311 vapor space.

Data to be collected under this revision (Revision 2) of the TSAP will be used to evaluate the effectiveness of the portable exhauster recently installed for the tank. Vapor samples taken previous to the issuance of this revision shall be analyzed in accordance with Revision 1.

\subsection{SAMPLING EVENT REQUIREMENTS}

Field vapor measurements and vapor samples will be taken from the West riser of catch tank 241-ER-311. Measurements and samples may be taken from other risers in accordance with this sampling and analysis plan.

Combustible gas level in the headspace of catch tank 241-ER-311 will be field-measured using portable or hand-held gas meters. The required field measurements are listed in Table 2-1. In addition, $60-\mathrm{ml}$ Hoke samples will be collected for more extensive analysis. The analytical requirements for the Hoke samples are specified in Table 2-1.

Prior to taking measurements and obtaining vapor samples, the sampling system shall be purged to assure that the sample system tubing is filled only with gas from the sample location. Field sampling shall be performed according to the following steps:

1. Record field measurements at the top of the riser. If the CGM reading is above $25 \%$ of the lower flammability limit (LFL), obtain one $60-\mathrm{ml}$ sample at that location.

2. Record field measurements at approximately the midpoint between the top and bottom of the riser and record the sample depth. If the CGM reading is above $25 \%$ of the LFL, obtain one $60-\mathrm{ml}$ sample at that location.

3. Record field measurements within the headspace of the tank and record the sample depth.

4. Obtain one $60-\mathrm{ml}$ sample from the sample depth (within the headspace). 
HNF-5375 Rev. 2

Table 2-1. Field Measurements

\begin{tabular}{|c|c|}
\hline Measurement & Measurement Method \\
\hline Combustible gas level & Combustible Gas Meter (CGM) \\
\hline Organic vapor & Organic Vapor Monitor (OVM) \\
\hline Ammonia & Calorimetric (Draeger) Tubes \\
\hline
\end{tabular}

Table 2-2. Required Analysis for 60-ml Hoke Samples

\begin{tabular}{|l|l|}
\hline Carbon Monoxide & Oxygen \\
Carbon Dioxide & Methane \\
Hydrogen & Nitrogen \\
Argon & Nitrous Oxide \\
Helium & Other Nitrogen Oxides \\
& Ammonia (estimated) \\
\hline
\end{tabular}

\subsection{QUALITY ASSURANCE}

All sampling and analysis activities shall be performed in accordance with the requirements in this TSAP and the appropriate references. Data resulting from activities and conditions that do not conform to requirements specified in this TSAP or references herein shall be controlled to prevent inadvertent use or flagged with appropriate cautions. Nonconforming sampling and analysis processes and information shall be identified, controlled, reported, and dispositioned as required by Nonconformance Item Reporting and Control (LMHC 1999).

\section{LABORATORY ANALYSIS}

Laboratories performing analyses in support of this TSAP shall have approved and implemented quality assurance project plans. The laboratories shall use calibration and calibration check standards appropriate for the analytical instrumentation being used. The criteria presented are goals for demonstrating reliable method performance. It is understood that the laboratories will follow established internal protocols for addressing QC failures. If sample QC failures occur or if some analyses cannot be performed (e.g., because of insufficient sample), analysts shall consult with RPP Process Engineering to determine the proper action. The performing laboratory should provide a suggested course of action at that time. All sample QC failures and limitations on the associated data shall be discussed in the narrative of the data report. Proper notification of all data not meeting QC requirements shall be included with the data. 


\section{SAMPLE COLLECTION}

Before sampling can be performed on a tank, a riser must be selected, inspected, and prepared for sampling. Safety hazards must be identified and special precautions must be taken if needed. Samples shall be taken and shipped to the 325 Laboratory by CPO in accordance with the Job Control System (JCS) work package.

\section{SAMPLE CUSTODY}

The 60-ml Hoke samples shall be uniquely identified with the date, sequential numbers, and initials of the Industrial Hygiene and Safety (IH\&S) technician. The sampling team shall initiate a chain-of-custody form as described in the work package. The sample number and the location (riser and elevation) at which the sample was obtained shall be recorded. Also, pertinent sampling information (e.g., unusual waste characteristics or sampling problems) should be noted in the Comments section of the chain-of custody form.

\subsection{ROLES AND RESPONSIBILITIES}

The main functions for this activity include an Overall Activity Lead, Field Measurements/Sampling, Laboratory Analysis, and Data Evaluation. All functions must be executed well in order to achieve the test objectives. The relationships among these functions are shown in Figure 3. The functions and the responsible organizations are further discussed below.

Activity Lead: RPP Process Engineering will act in this role. The Activity Lead shall coordinate the entire effort to assure that the desired data will be obtained as scheduled. Specific responsibilities include establishing test specification (i.e., prepare this test plan), assigning task responsibilities, and resolving sampling issues as they occur.

Field Measurement/Sampling: This function consists of pre-work planning activities and the actual field sampling. RPP Characterization Engineering will be responsible for completing the pre-work planning. Specific responsibilities include preparing work packages, performing Unreviewed Safety Question (USQ) screening, conducting field verification of sampling locations, and verifying final configuration of the test equipment. In addition, RPP Characterization Engineering will communicate and obtain necessary approvals from RPP Double-Shell Tank and Single-Shell Tank Engineering groups.

Characterization Project Operations (CPO) will be responsible for coordinating and performing the fieldwork. Specific responsibilities include arranging the necessary resources (personnel, materials, and equipment) for each sampling event and collecting data and samples as specified in this test plan. In addition to ensuring the availability of primary personnel (i.e., sampler and Industrial Hygiene and Safety), CPO will coordinate secondary support such as Radiation Protection and Crafts as needed. CPO will assure that field measurements are taken and recorded properly and that $60-\mathrm{ml}$ samples will be traceable through proper identification and chain-of-custody. 
HNF-5375 Rev. 2

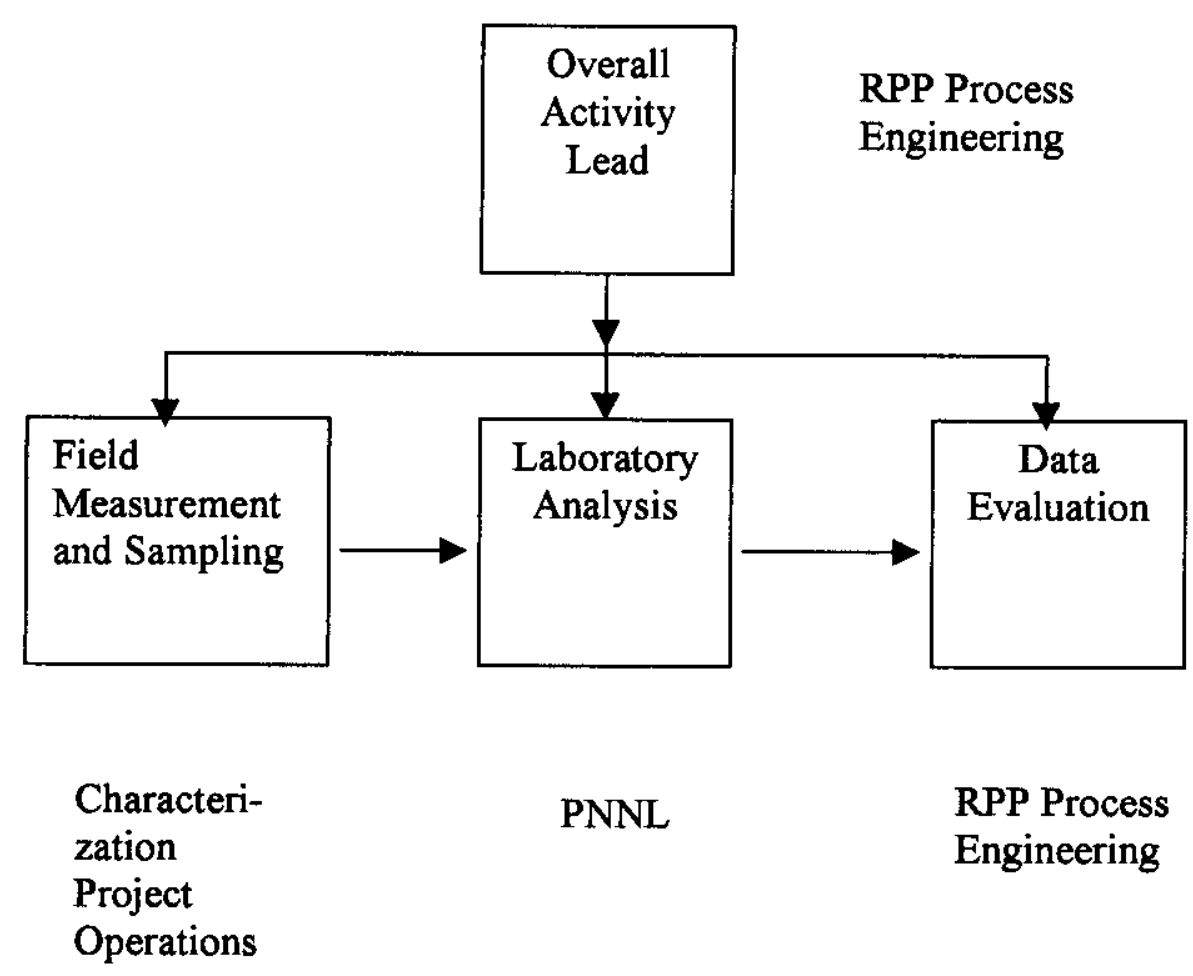

Figure 1. Lead Roles for the Sampling Activity 
Laboratory Analysis: Hoke samples will be analyzed at the Pacific Northwest National Laboratory for analytes listed in Table 2-2. Analysis shall be performed by analytical procedure PNNL-98523-284, Rev. 0 in accordance with the Gas Analysis Task (WBS 1.8) under the Flammable Gas Program.

Preliminary data will be made available to RPP Process Engineering as soon as they become available. The preliminary data shall be transmitted electronically via e:mail.

A final report shall be transmitted to the RPP Process Engineering and shall contain the following information at a minimum:

- Sample identification,

- All analytical results,

- Estimate of analytical precision, and

- Analytical procedure used.

Data Evaluation: Analytical data will be evaluated against process knowledge and existing data. RPP Process Engineering will be responsible for performing this evaluation. Results of the evaluation and a summary of the data will be documented in a report.

\subsection{SAFETY CONSIDERATIONS}

The catch tank may contain flammable gas, hazardous vapor, and radionuclides. A survey for hazardous vapor will be performed prior to gaining access to a tank. Also, radiation and hazardous vapor will be monitored during the test as necessary.

\subsection{REFERENCES}

LMHC, 1999, Nonconformance Item Reporting and Control, LMH-PRO-298, Rev. 0, Lockheed Martin Hanford Corporation, Richland, Washington. 


\section{DISTRIBUTION SHEET}

\begin{tabular}{|c|c|c|c|c|c|}
\hline \multirow{2}{*}{$\begin{array}{l}\text { To } \\
\text { Distribution }\end{array}$} & \multirow{2}{*}{\multicolumn{3}{|c|}{$\begin{array}{l}\text { From } \\
\text { Data Development and } \\
\text { Interpretation }\end{array}$}} & \multicolumn{2}{|l|}{ Page 1 of 1} \\
\hline & & & & \multicolumn{2}{|c|}{ Date $\quad 11 / 15 / 99$} \\
\hline \multicolumn{4}{|c|}{ Project Title/Work Order } & \multicolumn{2}{|l|}{ EDT No. N/A } \\
\hline \multicolumn{4}{|c|}{$\begin{array}{l}\text { RPP-5375, Rev. 2," "Sampling and Analysis Plan for Catch Tank } \\
\text { 241-ER-311 Vapor" }\end{array}$} & \multicolumn{2}{|c|}{ ECN No. $\quad$ ECN-656019 } \\
\hline Name & MSIN & $\begin{array}{c}\text { Text } \\
\text { With } \\
\text { A1l } \\
\text { Attach }\end{array}$ & Text Only & $\begin{array}{l}\text { Attach./ } \\
\text { Appendix } \\
\text { Only }\end{array}$ & $\begin{array}{l}\text { EDT/ECN } \\
\text { Only }\end{array}$ \\
\hline
\end{tabular}

Lockheed Martin Hanford Corp.

W. L. Adams

D. G. Baide

R. G. Brown

C. DeFigh-Price

R. A. Dodd

J. G. Field

K. M. Hodgson

G. D. Johnson

D. M. Nguyen

L. M. Sasaki

J. F. Sickels

S5-15

S5- 05

S7 -12

R2 -12

R3-72

R2-12

R2- 11

$\mathrm{R} 1-44$

$\mathrm{R} 2-12$

R2 -12

S7 -03

R2 - 12

S7 -12

D. D. Wanner

T.C.S.R.C.

R1-10

$x$
$x$
$x$
$x$
$x$
$x$
$x$
$x$
$x$
$x$
$x$
$x$
$x$
$x$

Lockheed Martin Services, Inc.

Central Files

B1-07 $\quad X$

Office of River Protection

DOE Reading Room

H2-53 X

Pacific Northwest National Laboratory

S. J. Bos

J. W. Brothers

P7-22

$\mathrm{K} 9-20$

M. W. Goheen

P7 -22

$X$
$X$
$X$ 